\title{
SÊRAT DARMASUNYA MACAPAT DAN KAKAWIN DHARMA ŚŪNYA DALAM HUBUNGAN TRANSFORMASI
}

\author{
Wiwien Widyawati Rahayu*
}

\begin{abstract}
Studies on Sêrat Darmasunya are conductedthrough literary and philological research. This is because both types of the studies cannot be absolutely separated. Sêrat Darmasunya is a holistic structure. Every element with a particular situation does not have a meaning in itself but,rather, the meaning is determined by its relationships with the other elements involved. A full meaning can be comprehended only if this element is integrated into the structure that is the overall elements. As a macapat song or a Javanese poetry, Sêrat Darmasunya should be understood by paying attention to the relationships between its elements as a part of the whole structure. The structure of Serrat Darmasunya should be analyzed based on the constituent elements of a poetry. These elements comprise intrinsic and extrinsic elements. Then, the critical edition of Serat Darmasunya was then analyzed through the approach of Intertextual-transformation theory. Serat Darmasunya provides information that between the manuscript and the text under study have similar contents. Although written with different metrum and in different languages, there are similarities in both explicit and implied meaning. Cultural environment shaped the mindset of the authors, whocame from the same environment that was the acculturation environment between Hindu and Javanese culture.
\end{abstract}

Keywords: Sêrat Darmasunya, macapat, literary, philological, transformation

\begin{abstract}
ABSTRAK
Penelitian terhadap Sêrat Darmasunya dilakukan secara literer dan filologis karena kedua macam bentuk penelitian ini tidak dapat dipisah-pisahkan secara mutlak. Sêrat Darmasunya merupakan sebuah struktur yang utuh. Tiap unsur dengan situasi tertentu tidak mempunyai arti sendirisendiri, tetapi ditentukan oleh hubungan dengan unsur-unsur lainnya yang terlibat. Makna penuh dapat dipahami hanya jika terinstegrasi ke dalam struktur yang merupakan keseluruhan dari satuan-satuan tersebut. Sebagai sebuah tembang macapat atau puisi Jawa, pemahaman terhadap Sêrat Darmasunya harus memperhatikan jalinan antarunsurnya sebagai bagian dari keseluruhan. Sêrat Darmasunya harus dianalisis strukturnya berdasarkan unsur-unsur pembentuk puisi. Unsur tersebut meliputi unsur intrinsik dan unsur ekstrinsik. Dari sini kemudian suntingan ilmiah dari Sêrat Darmasunya ditelaah secara literer dengan pendekatan teori intertekstual-transformasi.Sêrat Darmasunya memberikan informasi bahwa antara naskah dan teks yang diteliti memiliki kandungan isi yang sama. Meskipun ditulis dengan metrum dan bahasa yang berlainan, terdapat kesamaan makna baik yang tersirat maupun yang tersurat. Lingkungan budaya membentuk cara pikir para penyusun yang berasal dari lingkungan yang sama, yaitu lingkungan akulturasi antara kebudayaan Hindu dan Jawa.
\end{abstract}

Kata Kunci: Sêrat Darmasunya, macapat, literer, filologi, transformasi

* Jurusan Sastra Nusantara, Fakultas Ilmu Budaya, Universitas Gadjah Mada 


\section{PENGANTAR}

Abad ke-18 hingga ke-19 merupakan periode renaisans di Jawa. Pada saat itu Kraton Surakarta dan Yogyakarta banyak melakukan pemugaran terhadap karya sastra Jawa Kuna. Teks-teks sastra yang berbahasa Jawa Kuna banyak dijarwakan atau disadur ke dalam bahasa Jawa Modern.

Karya sastra gubahan kembali ini kebanyakan berupa karya sastra epik yang ada kesejajarannya dengan lakon-lakon wayang yang populer di masyarakat yang disampaikan dengan media pedhalangan dan yang berisi ajaran moral dan sikap hidup dalam bentuk simbol, seperti Serrat Wiwaha Jarwa, Sêrat Bratajuda, Sêrat Lokapala, Sêrat Arjuna Sasrabahu, dan Sêrat Rama Jarwa, yang masing-masing merupakan gubahan kembali dari karya sastra Jawa Kuna Arjunawiwaha, Arjunawijaya, Bharata Yuddha, dan Ramayana (Poerbatjaraka, 1957:150-157). Di samping karya sastra epik itu, ada juga karya sastra gubahan kembali yang berupa perumusan ajaran moral dan sikap hidup, salah satunya adalah Sêrat Darmasunya, yang dari pihak para pengamat sastra belum memperoleh perhatian dalam wujud penerbitan secara ilmiah (Sudewa, 1991:2).

Teks Darmasunya termasuk kategori teks jenis piwulang. Teks jenis piwulang memuat ajaran para orang soleh, suci, dan bijaksana yang mendasarkan pada ajaran kejawen yang dipadukan dengan ajaran keislaman (Behrend, 1990:ix).

Darmasunya berasal dari dua kata, darma dan sunya, darma berasal dari bahasa Sansekerta yang berarti 'kewajiban, kebenaran, tingkah laku yang baik, petunjuk, tempat suci' (Poerwadarminta, 1939:65), sedangkan sunya berasal dari bahasa Kawi (Jawa Kuna) sonya yang berarti 'sepi, kosong' (Poerwadarminta, 1939:579), dapat juga berarti 'kenikmatan kesadaran tertinggi yang tak terlukiskan' (Palguna, 1999:145). Oleh karena itu, Darmasunya dapat diartikan 'kebenaran sunyi' atau 'ajaran tentang kesunyian'. Isi dari teks Darmasunya ini adalah ajaran menuju kelepasan atau moksa yang merupakan tujuan tertinggi manusia menurut pandangan agama Hindu.

Berdasarkan sejarah perkembangannya, naskah Darmasunya mendapat sambutan hangat dan beragam dari masyarakat, terbukti dengan banyaknya naskah salinan yang tersimpan di berbagai perpustakaan di Indonesia, khususnya
Jawa. Bentuk sambutan masyarakat terhadap suatu teks itu beragam. Bentuk resepsi tersebut dapat berupa penyalinan, penerjemahan, penyaduran, pensyarahan, penciptaan kembali, serta pelisanan suatu teks (bdk. Teeuw, 1994:213; ChamamahSoeratno, 1994:213-215).

Sehubungan dengan hal tersebut, persoalan utamanya adalah bagaimana hubungan intertekstualitas teks Kakawin Dharma Śünya dengan teks Darmasunya Tembang Macapat. Permasalahan ini akan dijabarkan melalui tiga pertanyaan penelitian, yakni (1) bagaimana transformasi teks Kakawin Dharma Śūnya ke dalam teks Darmasunya Tembang Macapat, (2) transformasi struktur alur dan nama tokoh, dan (3) transformasi penokohan dan istilah. Untuk menjawab hal tersebut, dalam penelitian ini akan digunakan dua pendekatan, yaitu pendekatan filologi dan pendekatan sastra. Pertama-tama objek akan diterjemahkan dahulu ke dalam bahasa Indonesia. Hal ini dilakukan karena objek merupakan teks yang berbahasa Jawa Kuna dan berbahasa Jawa Baru. Setelah itu, teks dianalisis dengan menggunakan pendekatan intertekstual untuk mengetahui hubungan kedua teks ini.

Penelitian sejenis dengan penelitian ini pernah dilakukan oleh Istanti, dalam artikelnya yang berjudul "Transformasi dan Integrasi dalam Kesusastraan Nusantara: Perbandingan Teks Amir Hamzah Melayu dan Jawa" yang dimuat dalam Jurnal Humaniora Volume 22 No 3 Oktober 2010. Dalam artikelnya Istanti meneliti transformasi yang terjadi pada teks Amir Hamzah Melayu dengan teks Amir Hamzah Jawa. Dari penelitian itu didapatkan fakta bahwa terjadi beberapa perubahan antara teks Amir Hamzah Melayu dan Jawa. Perbedaan tersebut terdapat pada bagian Amir Hamzah mengislamkan para raja dari masyrik sampai maghrib. Di dalam teks Melayu dengan kalimat syahadat dan sesudah Islam para raja dibubuhi anting-anting, sedangkan di Jawa tanpa keduanya. Di dalam teks Melayu satu kata ("harta karun") di dalam teks Jawa diceritakan dalam satu episode, yakni penjelasan mengenai siapa Karun dan mengapa disebut harta karun. Adaptasi dan integrasi yang dapat dikemukakan di antaranya nama-nama tokoh disesuaikan dengan lafal Jawa (Buzurjamir-Betaljemur; Quraisy peri-Kuraisin; Bahtik-Bestak; Mahira Negara-Muninggar). 
Serupa dengan penelitian Istanti, dalam artikel ini juga akan diungkapkan transformasi yang terdapat dalam Teks Serrat Darmasunya dengan Teks Kakawin Dharma Śūnya.

\section{TEKS KAKAWIN DHARMA ŚŪNYA DAN TEKS SÊRAT DARMASUNYA}

Teks Kakawin Dharma Śūnya dalam tradisi Bali termasuk jenis teks tutur. Secara harfiah, kata tutur berarti 'kesadaran, ingatan' (OJED:2084). Yang dimaksud teks tutur adalah sekelompok teks yang memuat uraian tentang berbagai kenyataan (sarwatattwa) berdasarkan berbagai tingkatan kesadaran.

Kakawin Dharma Śūnya memuat puncak pencapaian sang wiku yang mengembara dari satu tingkat kenyataan ke tingkat kenyataan lainnya, hingga akhirnya sampai pada kenyataan yang Nol (sempurna). Merasakan Darmasunya adalah tujuan akhir menjadi wiku. Setelah itu, apa yang dirasakannya dalam Darmasunya dititipkan ke dalam Kakawin Dharma Śūnya (Palguna, 1999:196). Disebutkan pula bahwa sunya adalah tingkat kesadaran yang sempurna dan tidak ditentukan oleh ruang dan waktu. Oleh karena itu, untuk mencapai kelepasan terakhir atau moksa tidak harus dilakukan menyepi secara fisik, tetapi dapat dilakukan di mana saja.

Kakawin Dharma Śūnya yang merupakan karya seorang kawi wiku dari Bali, Kamalanatha tersebut kemudian ditransformasikan ke dalam bentuk tembang macapat oleh seorang pujangga kraton Surakarta, Yasadipura II pada abad 19. Sebagai penyambut dari Kakawin Dharma Śunnya, Yasadipura II memiliki kesenjangan tempat, waktu, dan latar yang berbeda dengan saat teks Kakawin Dharma Śūnya ditulis.

Abad ke-18 hingga ke-19 merupakan periode renaisans di Jawa. Pada saat itu, Kraton Surakarta dan Yogyakarta banyak melakukan pemugaran terhadap karya sastra Jawa Kuna. Teks-teks sastra yang berbahasa Jawa Kuna banyak dijarwakan atau disadur ke dalam bahasa Jawa Modern. Salah satu hasil karya sastra Jawa Kuna yang ditulis kembali pada zaman Surakarta adalah teks Dharma Śünya. Adanya rentang waktu yang panjang antara saat Kakawin Dharma Śunnya ditulis oleh Kamalanatha dan saat pujangga Yasadipura II menyambut teks tersebut menjadikan timbulnya perbedaan bahasa, metrum, serta budaya mengingat Kakawin Dharma Śūnya ditulis di Bali. Perbedaan bahasa, metrum, serta budaya tersebut tidak memengaruhi perbedaan isi, artinya ajaran yang terkandung dalam Sêrat Darmasunya sama dengan yang terdapat pada latar penciptaannya, yakni Kakawin Dharma Śūnya. Namun demikian, untuk beberapa istilah terdapat perbedaan, misalnya nama tokoh Dewi Saraswati yang terdapat pada bagian manggala Kakawin Dharma Sunnya tidak ditemukan pada teks Sêrat Darmasunya. Hal itu terjadi karena di Jawa tokoh Saraswati tidak begitu dijunjung seperti di Bali, tetapi Dewa Kama, dewa asmara dan keindahan lebih sering dipuja di Jawa (Zoetmulder, 1985: 204).

Kakawin Dharma Śūnya memuat puncak pencapaian sang wiku dari satu tingkat kenyataan ke tingkat kenyataan lainnya, sampai akhirnya mencapai pada tingkat kesadaran yang sempurna. Ajaran mencapai kesempurnaan hidup yang termuat dalam Kakawin Dharma Śūnya tersebut berkaitan dengan proses kehidupan, kematian, dan kelahiran kembali.

Menurut hukum aksi dan reaksi, manusia setiap hari pasti mengalami akibat dari setiap reaksi, dan setiap hari akan mengalami kenikmatan dan kesengsaraan. Ketika seseorang mati semua momentum reaktifnya (samskara) telah habis dan tak ada samskara baru yang terbentuk lagi sehingga pikiran akan menjadi murni dan akan melebur ke dalam kesadaran kosmis. Peleburan permanen ini dalam bahasa Sansekerta disebut moksha. Untuk menghabiskan seluruh samskara dan tidak membuat samskara baru selama proses berlangsung adalah sulit sekali. Oleh karena itu, setiap tubuh fisik yang mati masih tetap mengalami reaksi. Untuk melahirkan kembali pikiran itu, diperlukan tubuh lain. Konsep ini mengacu pada reinkarnasi atau kelahiran kembali.

Berkaitan dengan konsep reinkarnasi, Ananda Marga menerangkan bahwa hidup adalah keadaan paralel antara pikiran dan tubuh. Ada panjang gelombang tertentu yang terkait dengan tubuh, dan juga ada suatu panjang gelombang tertentu yang terkait dengan pikiran. Bila panjang gelombang itu paralel, kita memiliki kehidupan. Tetapi jika tubuh kita mengalami sakit, terjadi perubahan pada panjang gelombang fisik dan keadaan paralel tadi hilang sehingga tubuh fisik menjadi mati. 
Di samping itu, juga ada kematian sebab spiritual. Orang yang secara terus-menerus mengembangkan spiritualnya, pikirannya akan terserap ke dalam kesadaran kosmis, yang memiliki getaran dari panjang gelombang yang tak terbatas dan digambarkan sebagai garis lurus. Bila keadaan pikiran mencapai keadaan paralel dengan keberadaan kosmis, orang itu akan kehilangan keadaan paralelnya dengan tubuh fisiknya. Dalam hal ini, orang itu meninggalkan tubuhnya dan mencapai keadaan moksha. Hal itu bukan berarti mati dalam pengertian ketiadaan, tetapi manunggal ke dalam keindahan tak terbatas.

\section{TRANSFORMASI TEKS KAKAWIN DHARMA ŚŪNYA KE DALAM TEKS SÊRAT DARMASUNYA}

Karya sastra dari masa ke masa selalu mendapat sambutan sesuai dengan jamannya. Setiap teks sastra dibaca dan harus dibaca dengan latar belakang teks-teks lainnya; tidak ada sebuah teks pun yang sungguh-sungguh mandiri, dalam arti bahwa penciptaan dan pembacaannya tidak dapat dilakukan tanpa adanya teks-teks lain sebagai teladan maupun kerangkanya (Kristeva dalam Teeuw, 2003:120). Hal itu berarti pemahaman teks baru memerlukan latar belakang pengetahuan tentang teks-teks yang mendahuluinya. Hal itu menandakan bahwa suatu karya sastra tidak tercipta dalam kekosongan budaya. Sebuah karya sastra akan mati, kering, dan stagnan jika tidak dihidupkan kembali oleh pembaca pada zaman selanjutnya. Dalam hal ini, sebuah teks karya sastra akan mengalami transformasi sesuai dengan minat pembacanya.

Menurut Junus (1985:87-88), istilah transformasi dapat dipahami sebagai pemindahan atau penjelmaan suatu teks ke dalam teks lain. Pemindahan atau penjelmaan ini terjadi pada tataran formal dan abstrak. Disebut transformasi formal apabila pemindahan atau penjelmaan pola, alur cerita, karakter, dialog, tema, dan sebagainya dari satu teks ke teks lain dapat ditangkap dengan jelas. Adapun transformasi abstrak yaitu apabila ide atau wacana suatu teks meresap ke dalam teks lain tidak dalam tataran formal (Dewojati, 2000:239-240). Selain itu, dalam proses transformasi biasanya juga terjadi modifikasi yang berupa pengubahan, penyesuaian, perbaikan, dan perlengkapan terhadap teks yang ditransformasikan.

Berkaitan dengan masalah transformasi, Barthes (1981:31-32) menyatakan intertekstualitas adalah himpunan atau kombinasi berbagai teks dalam sebuah teks. Dalam keadaan tertentu hasil karya yang ditulis itu melahirkan suatu bentuk atau genre baru. Bentuk atau genre baru itu mungkin merupakan eksperimen penyambutnya dalam menghasilkan karya yang berbeda dari apa yang pernah ditulis oleh pengarang sebelumnya.

Sêrat Darmasunya yang digubah dalam bentuk tembang macapat merupakan hasil transformasi dari bentuk Kakawin Dharma Śunnya. Adanya hubungan antara kedua karya sastra ini, sejara eksplisit terlihat dari adanya penyebutan bahwa penyaduran Sêrat Darmasunya bersumber dari kitab Kakawin Dharma Sūnya pada bagian kolofon. Yasadipura II selaku penyadur mengakui bahwa dirinya sekedar menjalankan perintah dari putra mahkota Raja Surakarta agar melakukan penulisan ulang atas Kakawin Dharma Sunya ke dalam bentuk terjemahan bahasa Jawa Baru.

Penyambut teks Serat Darmasunya dalam hal ini mencoba menghasilkan suatu karya sastra yang berbeda dari penulis sebelumnya. Kakawin Dharma Śūnya yang ditulis dengan menggunakan bahasa dan pola persajakan Jawa Kuna, seperti metrum Jagaddita, Girisa, Jalodatigati, Prethwitala, Malini, dan sebagainya selanjutnya oleh pengarang Sêrat Darmasunya diubah dengan menggunakan bahasa dan pola persajakan bahasa Jawa Baru, seperti Dhandhanggula, Sinom, Asmaradana, Kinanthi, dan sebagainya.

Walaupun secara fisik antara teks Kakawin Dharma Sūnya dan Serat Darmasunya berbeda, namun isi ajaran atau tema kedua teks tersebut sama, dan tidak terdapat demitefikasi atau pertentangan isi. Tema atau isi ajaran yang terkandung dalam Kakawin Dharma Sūnya meresap ke dalam Sêrat Darmasunya dalam bentuk transformasi formal, yakni pemaparan cerita atau ajaran dalam Sêrat Darmasunya urutannya sama dengan yang terdapat dalam teks Kakawin Dharma Sūnya. Pada bagian pertama baik teks Serat Darmasunya maupun teks Kakawin Dharma Sūnya memuat bait manggala yang berisi pengagungan kepada sang kawiswara yang mengilhami sang kawi dalam membuat syair. Pada bagian kedua, kedua teks tersebut 
berisi tentang pemaparan isi ajaran pokok, yaitu jalan atau cara untuk mencapai Paramasiwa. Pada bagian ketiga, kedua teks berisi epilog yang memuat apologi sang kawi yang telah selesai membentangkan ajaran Dharma Śūnya. Selain itu, juga berisi kolofon atau waktu penulisan teks. Transformasi isi yang terjadi pada Sêrat Darmasunya dan Kakawin Dharma Súnya bisa dilihat pada tabel di bawah ini.

Tabel 1

Transformasi Isi pada Sêrat Darmasunya dan Kakawin Dharma Śūnya

\begin{tabular}{|c|c|c|}
\hline No & Sêrat Darmasunya & Kakawin Dharma Śūnya \\
\hline \multirow[t]{3}{*}{1} & Pupuh II Asmaradana : 12-13 & Pupuh V Bait 1 \\
\hline & $\begin{array}{l}\text { Sawêneh Pandhita malih/ mangkana ing kawruh ira/ yen } \\
\text { wus têtêp ing tingale/ tumêka maringlkamuksan/ tan arsa } \\
\text { yen kesaha/ mênêng kewala anulus/jagat sampun kaêbêkan// } \\
\text { Saananing rat wus esthi/tan lor tan kidul tan wetan/tan nora } \\
\text { angetung kulon/pan wus mantêp ing paningal/wus tan darbe } \\
\text { panêdha/mengo kewala ing kalbu/tan ana ingkang kacipta// }\end{array}$ & 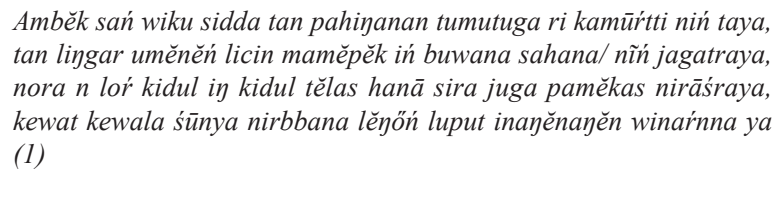 \\
\hline & $\begin{array}{l}\text { Tersebutlah seorang pendeta, menurutnya apabila sudah } \\
\text { tetap penglihatannya, sampailah pada muksa,hanya diam } \\
\text { saja tanpa rintangan, dunia sudah punah. Segala yang ada } \\
\text { di dunia sudah tidak berarti, baik utara, selatan, timurr, } \\
\text { maupun barat, bila sudah mantap arah pandangannya, } \\
\text { sudah tidak punya keinginan, selalu terbuka hatinya, } \\
\text { tidak menginginkan apapun }\end{array}$ & $\begin{array}{l}\text { Batin Sang Wiku sempurna tak terbatas, sejauh penampakan } \\
\text { ketiadaan. Tak tergoyahkan, diam sempurna memenuhi semua } \\
\text { buana di jagad raya.Tiada utara, selatannya selatan habis, ia } \\
\text { hanya sisa-sisa kebebasan terakhir. Semata sunya nirwana } \\
\text { lengang, tak terjangkau memikirkannya, menceritakannya }\end{array}$ \\
\hline \multirow[t]{3}{*}{2} & Pupuh II Asmaradana : 20 & Pupuh V Bait 4 \\
\hline & $\begin{array}{l}\text { sinimpên tan kêna lair/ dadya rambah ênêngira²/ } \\
\text { pêtênge dasendriyane/ sirnane tanpa karana/ têmahan kang } \\
\text { pangucap/ swara mijil sangking ka[6]lbu/ asri ngêbêki } \\
\text { bawana// }\end{array}$ & 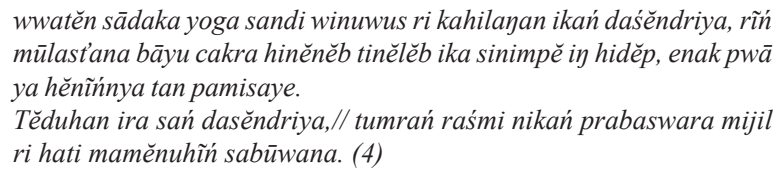 \\
\hline & $\begin{array}{l}\text { Tersebutlah pendeta yang mengajarkan sabda jati, } \\
\text { membicarakan hilangnya dasendriya (10 keinginan) }\end{array}$ & $\begin{array}{l}\text { Tersebutlah orang yang menggelarkan sarana yoga persatuan } \\
\text { Diceritakan saat sepuluh indriya dihancurkan }\end{array}$ \\
\hline \multirow[t]{3}{*}{3} & Pupuh IV. Sinom : 18 & Pupuh XI Bait 1 \\
\hline & $\begin{array}{l}\text { wontên warah ing pandhita/ lakonana pan prayogi/ } \\
\text { sarate }{ }^{4} \text { angrusak ing tyas/ tyas ingkang } \underline{\underline{5}} \text { harda sahardi/ kang } \\
\text { sukêr nora bêcik/ yeku wawasên den gupuh/ dadya hening } \\
\text { tyasira/[11]tan ana kang nênukêri } \underline{6}^{6} / \text { alungguha sira mênênga } \\
\text { kewala// }\end{array}$ & $\begin{array}{l}\text { hana warah ira sań purusa Ikasana, śarana niy amunah hati mari } \\
\text { wiyasa, yatika pahawasěn Ikasana satata, pāla nika pahěnĩn }\end{array}$ \\
\hline & $\begin{array}{l}\text { Ada ajaran dari seorang pendeta, kerjakanlah yang menarik, } \\
\text { syaratnya melebur hati, yaitu hati yang penuh nafsu, hati } \\
\text { yang kotor tidak baik, yaitu perhatikan dengan segera, } \\
\text { sehingga hatimu bisa hening, tidak ada yang mengotori, } \\
\text { duduklah engkau dan diam saja }\end{array}$ & $\begin{array}{l}\text { Ada ajaran beliau Sang Purusa, laksanakanlah, sarana } \\
\text { memunahkan hati dari ikatan.Perhatikan dengan seksama, } \\
\text { laksanakan selalu. Pahalanya hening bersinar-sinar }\end{array}$ \\
\hline
\end{tabular}

\footnotetext{
1 Naskah G : marang

2 Naskah G : rapêt hênêngira

3 Naskah G : pêtênging

4 Naskah G : sarating

5 Naskah G : ing tyasing

6 Naskah G : nyênyukuri
} 


\begin{tabular}{|c|c|}
\hline No & Sêrat Darmasunya \\
\hline \multirow[t]{3}{*}{4} & Pupuh VII. Pocung bait 9-17 \\
\hline & $\begin{array}{l}\text { Wontên warah ing Pandhita kang winuwus/ kalangkung } \\
\text { engêtnya/ warahing sawiji-wiji/ wontên ta ing sarira nira } \\
\text { punika// } \\
\text { Pan pinisah datan tumut bu\{wa\}neku/ siyang kulêm datan/ } \\
\text { ana ing sariranekil kawisayan kamuktyan tan neng sarira/l }\end{array}$ \\
\hline & $\begin{array}{l}\text { Alkisah ada ajaran Pendeta yang sangat tajam ingatannya, } \\
\text { setiap ajarannya ada di badanmu. Yang terpisah tidak } \\
\text { turut serta di dunia, siang dan malam tanpa ada } \\
\text { ditubuhmu. Pasangan, kekayaan tidak (ikut) dalam diri. }\end{array}$ \\
\hline \multirow[t]{2}{*}{5} & Pupuh VII Pocung bait 18-23 \\
\hline & 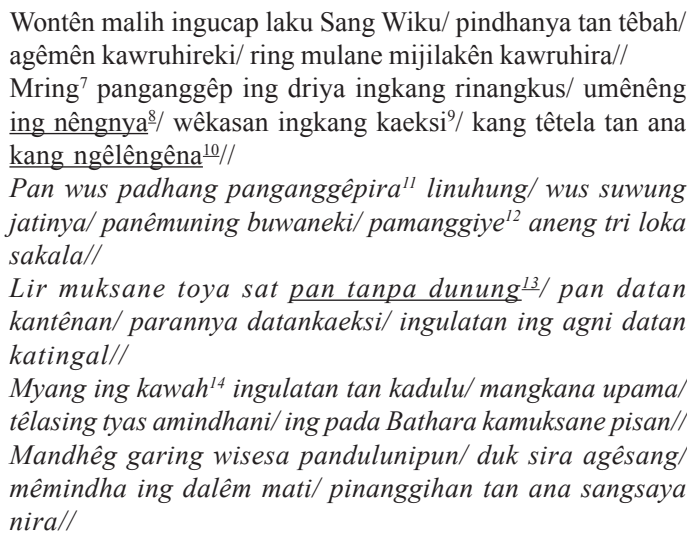 \\
\hline
\end{tabular}

Ada lagi sabda sang wiku, kemiripannya tidak jauh, pakailah pengetahuanmu ini, oleh karenanya melahirkan ilmumu. Pendapat di hatimu yang dipegang, akhirnya yang terlihat, yang jelas tidak ada dipikirkan. Jika sudah jelas pendapatmu yang luhur, sudah benar-benar kosong dunia ini, ketemunya di tiga tempat semua.Seperti hilangnya air yang kering tanpa arah, tak terkirakan, tujuannya tidak terlihat ... dst

\section{TRANSFORMASI STRUKTUR ALUR DAN NAMA TOKOH}

Sêrat Darmasunya sebagai wujud transformasi dari Kakawin Dharma Sūnya ternyata memiliki alur cerita yang sama dengan teks Kakawin Dharma Śūnya. Namun demikian, pemaparan cerita dalam teks Sêrat Darmasunya lebih ringkas jika dibandingkan dengan teks Kakawin Dharma Śūnya. Hal itu menunjukkan

$\begin{array}{lll}7 & \text { Naskah G } & \text { : Ing } \\ 8 & \text { Naskah G } & \text { : enengnya } \\ 9 & \text { Naskah G } & \text { : pangaksi } \\ 10 & \text { Naskah G } & \text { : kangên-angêna } \\ 11 & \text { Naskah G } & \text { : pangidhêpira } \\ 12 & \text { Pamanggihe } & \\ 13 & \text { Naskah G } & \text { : tanpa dumunung } \\ 14 & \text { Naskah G } & \text { : wayah }\end{array}$

Kakawin Dharma Ś̄̄nya

Pupuh XVII Bait 7

hana ta warah ginuhya de sań, purusa tiśaya durllaba bāra mewĕh hana riyawakta nitya tan sah, ndan ika ya tan tumūt in sarwwa wastu. (7)

Ada ajaran dirahasiakan oleh Sang Purusa, amat sulit berat dan pelik. Ada di dalam dirimu, tetap tak terpisahkan. Namun demikian ia tidak ikut dalam segala benda

Pupuh XIX Bait 3-4

wahu mijil rgěppati ya waysulnta umněń, wkasana riń wulat wu/lati tan hanā kāyĕnayĕn hiděpta malilan, paramaśesa nírbbana suwuń těmunta nikanań triloka sakala. (3)

kadi ta ya muksa niń bańuklā ndatan patuduhan paranya numisep, winulatan in apuy pwa juga tan katon// mway ika rin kawah ya tan hana, ya ta pada niń manah tlas amindha riń pada batara muksa ya pisan, madga wiśesa riń sakala niskala n dug ahurip maminda rị hati. (4)

Ada jalan Sang Wiku sejati menunggal, tidak jauh, pikiranmu pusatkan. Pada awal manah baru muncul pusatkan matikan, kembalikan manah itu diam. Selanjutnya pada pandangan memandang, tak ada dipikir, pikiranmu bebas. Sunyi sempurna tertinggi luar biasa kan kau temukan di tiga dunia sakala.Seperti hilangnya air mendidih tidak terlacak ke mana menguap ... dst

adanya modifikasi pada teks Sêrat Darmasunya, yakni berupa pengubahan dan penyesuaian dalam bentuk tembang macapat. Selain itu, juga terdapat perbedaan penyebutan nama tokoh maupun istilah di antara kedua teks tersebut yang disebabkan adanya perbedaan budaya, latar, bahasa, dan waktu penulisan. Contoh perbedaan nama tokoh, yakni Paramasiwa yang terdapat dalam Kakawin Dharma Súnya tidak ditemukan dalam teks Sêrat Darmasunya, tetapi terdapat tokoh Sang Batara Ji dalam Sêrat Darmasunya yang mengacu pada referen yang sama. Selain itu, tokoh Hyang Paramesthi yang terdapat dalam Kakawin Dharma Sunnya, dalam Sêrat Darmasunya diganti menjadi Batara Girinata. Pada bagian manggala Kakawin Dharma Śn̄nya terdapat dua tokoh yang dapat dianggap sebagai istadevata bagi sang kawiswara sehingga berhasil membuat kakawin. Tokoh yang 
memberikan kekuatan pada sang kawiswara tersebut, yaitu Hyang Paramesthi yang telah memberikan anugerah berupa kesucian pikiran kepada sang kawiswara. Selain mendapatkan kesucian pikiran, sang kawiswara juga telah berhasil manunggal dengan Dewi Saraswati, yakni dewi ilmu pengetahuan, sehingga semua ucapan sang kawi terjadi. Dalam Kakawin Dharma Súnyatersebut tokoh Hyang Paramesthi mengacu pada kebenaran, sedangkan Dewi Saraswati mengacu pada keindahan. Dengan demikian, Kakawin Dharma Śunya selain mengandung unsur kebenaran juga memiliki unsur keindahan (Palguna, 1999).

Pada manggala Serrat Darmasunya, tokoh Hyang Paramesthi dan Dewi Saraswati tidak ditemukan. Dalam Serrat Darmasunya disebutkan bahwa tokoh yang telah memberikan anugerah pada sang kawi sehingga sangat pandai dalam segala pengetahuan, yakni Hyang Girinata. Dalam tradisi Jawa tokoh Hyang Paramesthi dan Dewi Saraswati tidak dikenal.

Selain itu, pada bagian manggala kedua teks Darmasunya tersebut berisi permintaan maaf sang kawi yang telah memberanikan diri membuat kakawin. Dalam Kakawin Dharma Sūnya disebutkan sang kawi membuat kakawin karena dilandasi rasa bakti pada sang guru (Malinata) yang telah memberikan ajaran kepadanya (Kamalanatha). Sebaliknya, dalam teks Serrat Darmasunya disebutkan sang pujangga membuat tembang karena dilandasi rasa bakti pada Paduka
Yang Mulia (raja) yang telah memberinya petunjuk. Dengan demikian, dapat diketahui bahwa Kakawin Dharma Sunnya merupakan hasil karya seorang murid (Kamalanatha) yang dipersembahkan untuk sang guru (Malinatha) karena sang guru telah memberinya teladan berupa ajaran kebenaran. Sementara itu, Sêrat Darmasunya merupakan hasil karya seorang pujangga (Yasadipura II) yang dipersembahkan untuk sang raja yang telah memberinya petunjuk.

\section{TRANSFORMASI PENOKOHAN DAN ISTILAH}

Nama-nama tokoh dan istilah dalam teks Serat Darmasunya mengalami penyesuaian dengan tradisi Jawa. Walaupun nama tokoh dan istilah tersebut berbeda, tetapi mengacu pada makna yang sama. Nama-nama tokoh seperti Kamalanatha, Malinatha, Hyang Paramesthi, Dewi Saraswati, Sang Wiku, Sang Sinamaya, raksasa Mura, Janardhana, Hyang Iswara, Hyang Siwa, Paramasiwa tidak ditemukan dalam teks Sêrat Darmasunya. Dalam teks Kakawin Dharma Śūnya tokoh Kamalanatha sebagai pengarang kakawin, dalam teks Sêrat Darmasunya padanannya adalah Yasadipura II. Malinatha yang merupakan guru dari Kamalanatha padanannya adalah sang nerpati siwi (putra raja di Kraton Surakarta). Hyang Paramesthi padanannya adalah Bathara Guru. Sang Raja Yogi dan Sang Wiku padanannya adalah Begawan Yogiswara atau Empu Yogiswara.

Tabel 2

Transformasi Tokoh Cerita

\begin{tabular}{lll}
\hline No & Sêrat Darmasunya & Kakawin Dharma Ś̄̄nya \\
\hline 1 & Sang Pujangga (bait 1) & Sang Kawi (bait 1) \\
2 & Hyang Girinata (bait 3) & Hyang Paramesthi (bait 2) \\
3 & Sri Batara Danardhono/Batara WIsnu (bait 19) & Janardhana (bait 14) \\
4 & Kawiswara (bait 3) & Kawiswara (bait 2) \\
& - & Raksasa Mura \\
5 & Batara Guru (bait 20) & Hyang Iswara (bait 14) \\
& Sang Hyang Wisnu Dewa, Resi (bait 20) & Dewaresi, Dhatra, Wisnu (bait 14) \\
6 & Begawan Yogiswara (bait 26), Empu Yogiswara (bait & Sang Raja Yogi (bait 18) \\
& 27) & \\
7 & Pendeta (Asmaradana:1) & Sang Wiku (bait 19, 26) \\
8 & - & Sang Sinamaya (bait 24, 25, 27,143,158,162) \\
\hline
\end{tabular}




\begin{tabular}{|c|c|c|}
\hline No & Sêrat Darmasunya & Kakawin Dharma Śūnya \\
\hline 9 & Batara Siwah (Asmaradana: 16) & Bhatara Siwa \\
\hline 10 & Batara Suksma (Asmaradana: 24) & Bhatara yang halus (bait 32) \\
\hline 11 & Hyang Suksma (Asmaradana: 28) & Bhatara Siwa (37) \\
\hline 12 & Sang Murtijati (Asmaradana: 33) & Bhatara Siwa \\
\hline 13 & Sang Maha Pendeta (Asmaradana:37) & Sang Maha Purusa $(40,140)$ \\
\hline 14 & Hyang Pancasetyadimurti (Kinanthi:1) & Hyang Pancasakti (bait 41) \\
\hline 15 & Hyang Girinata (Kinanthi: 2) DG:15 & Hyang Siwa (bait 41) \\
\hline 16 & Batara Brama (Kinanthi: 4) & Hyang Brahma (bait 42) \\
\hline 17 & Sang Wisnumurti (Kinanthi:6) & Wisnu yang nyata (bait 44) \\
\hline 18 & Hyang Jagadnata (Kinanthi:8) & Rudra (bait 45) \\
\hline 19 & Sang Hyang Mahaiswara (Kinanthi:10) & Sang Hyang Iswara (bait 47) \\
\hline 20 & Sang Batara Sakti (Kinanthi:11) & Hyang Sakti (bait 47) \\
\hline 21 & Sang Manon (Kinanthi:14-15) & - \\
\hline 22 & Sang Batara Ji/ Aji (Kinanthi:15) & Bhatara Hyang Siwa (bait 49) \\
\hline 23 & Sang Manon (Kinanthi:20) & Atma (bait $52,76,78$ ) \\
\hline 24 & Tripurussa/Hyang Karya (Kinanthi:23) & Sang Paramadimurti (bait 53) \\
\hline 25 & Hyang Guru (Sinom:2) & Bhatara Hyang Siwa (bait 55) \\
\hline 26 & Pendita (Sinom:7) & Wiku (bait 61) \\
\hline 27 & Pendeta Yogiswara (Sinom:12) & Yogi (bait 62) \\
\hline 28 & Dang Hyang Wisesa (Sinom:17) & - \\
\hline 29 & Pendeta Sinom 18,22 DG:7,9 & Sang Purusa (bait $65,74,81,82,84,141,154,163$ \\
\hline 30 & Sanga Maharsi (Sinom:20) & \\
\hline \multirow[t]{2}{*}{31} & Sang Hyang Wisesa (sinom 27) & \\
\hline & Sang Maha Wiku (DG:7 & \\
\hline 32 & Sang Pendeta (DG:7) & Sang Purusa (81) \\
\hline 33 & Sang Maha Wiku (DG 7) & Sang Purusa (82) \\
\hline 34 & Sang Pendeta (DG 9) & Sang Purusa (84) \\
\hline 35 & $\begin{array}{l}\text { Arca berbentuk Hyang Girinata (DG 15), Sang Hyang } \\
\text { Arca (DG 15) }\end{array}$ & Arca berwajahkan Hari, Hara, Rudra (92) \\
\hline 36 & Hyang Giriaji (DG 18) & Paramasiwa, Sadasiwa, Rudra (96) \\
\hline 37 & Sri Batara Guru (DG 18) & Hari, Hara, Sambhu (96) \\
\hline \multirow[t]{2}{*}{38} & Sri Batara Guru (DG 19) & Sang Hyang (97) \\
\hline & & Paramasiwa, Sadasiwa, Pasupati (98) \\
\hline 39 & Darma Hari (DG 20) & Darma Hari (98) \\
\hline 40 & BataraGuru (DG 20) & - \\
\hline 41 & Brahma Sakala Widya (DG 20) & Brahma Sakala Widya (99) \\
\hline 42 & Sura, Resi, gana, dewa (DG 20) & Sura, resi, gana, dewa (99) \\
\hline 43 & $\begin{array}{l}\text { Batara brama, Batara Kala, ditya, raksasa, resi guru, } \\
\text { dewa-dewi (DG 21) }\end{array}$ & - \\
\hline 44 & - & Om Sang Hyang Atma seperti Paramasiwa (100) \\
\hline 45 & Atma (DG 24) & Atma (101) \\
\hline 46 & Di kaki Sang Hyang Jagad (DG 26) & Di kakiMu (104 \\
\hline 47 & Atma (DG 30) & Atma (105) \\
\hline 48 & Sang Hyang Atma (DG 31) & Sang Hyang Atma (107) \\
\hline
\end{tabular}




\begin{tabular}{|c|c|c|}
\hline No & Sêrat Darmasunya & Kakawin Dharma Śūnya \\
\hline 49 & Sang Hyang Suksma (DG 34) & Sang Hyang Darma (112) \\
\hline 50 & Hyang Suksma (DG 36) & - \\
\hline 51 & Sang Hyang Suksma DG 39) & - \\
\hline 52 & Sang Hyang Agni (DG 40) & - \\
\hline 53 & Sang Pandhita (DG 42) & Yogi (115) \\
\hline 54 & - & Paramasiwa (115) \\
\hline 55 & Sang Hyang Hening (VI.Sinom 3) & Sang Hyang Atma (118) \\
\hline 56 & - & Empat Sakti Siwa (118) \\
\hline 57 & - & Kerabat Sang Wiku (124) \\
\hline 58 & Sang pandhita (sinom 10) & Sang Wiku (129) \\
\hline 59 & Sang Pandeta (sinom 10) & Wiku (129) \\
\hline 60 & Sang Pendeta (sinom 11) & \\
\hline 61 & Sang Maharsi (sinom 12) & Yogi (132) \\
\hline 62 & Sang Maharsi (sinom 13) & Yogi (135) \\
\hline 63 & Sang Maha Resi (sinom 14) & Yogi (136) \\
\hline 64 & - & Sang Wiku (138) \\
\hline 65 & - & Sang Wiku (139) \\
\hline 66 & - & Paramasiwa \\
\hline 67 & Sang Maharsi (sinom 16) & Sang Mahapurusa (140) \\
\hline 68 & Sang Hyang Maharsi (sinom 17) & Sang Purusa (141) \\
\hline 69 & Sang Pandeta (sinom 18) & Sang Wiku (142) \\
\hline 70 & Tabir Hyang Jati (sinom 21) & Sang Sinamaya (143) \\
\hline 71 & Sang Paramarta (sinom 21) & Sang Paramartha (143) \\
\hline 72 & Sang Hyang Surya (sinom 21) & Matahari (144) \\
\hline 73 & - & Peliklah Yang Melihat (144) \\
\hline 74 & - & Dipenuhi oleh Yang Melihat (145) \\
\hline 75 & Sang Maharsi (sinom 23) & Sang Raja Pertapa (146) \\
\hline 76 & Hyang Jati (sinom 25) & Ia adalah Pelindung (147) \\
\hline 77 & Sang Pendeta ( sinom 23) & Berwujudkan Hyang (151) \\
\hline 78 & Sang Mahayogi (VII.Pocung 1) & \\
\hline 79 & Sang Maha Resi (pocung 3) & - \\
\hline 80 & Sang Maharsi (pocung: 7) & Sang Yogi (152) \\
\hline 81 & Batara (pocung : 8) & Bhatara Hyang (152) \\
\hline 82 & Sang Maha Pendita (pocung: 8) & - \\
\hline 83 & Pendeta (pocung: 9) & Sang Purusa (154) \\
\hline 84 & Sang Resi (pocung:12) & Sang Raja Pertapa (157) \\
\hline 85 & - & Kaki Bhatara (157) \\
\hline 86 & - & Sang Sinamaya (158) \\
\hline 87 & Sang Wiku (pocung:13) & - \\
\hline 88 & Sang Hyang Wisesa (pocung:14) & - \\
\hline 89 & Hyang Wisesa (pocung; 15) & - \\
\hline 90 & Hyang (pocung:16) & - \\
\hline 91 & Sang Wiku (pocung : 18) & Sang Wiku (159) \\
\hline
\end{tabular}




\begin{tabular}{|c|c|c|}
\hline No & Sêrat Darmasunya & Kakawin Dharma Śūnya \\
\hline 92 & Batara (pocung:22) & Bhatara (160) \\
\hline 93 & Wiku (pocung 24) & Sang Wiku (161) \\
\hline 94 & Yang Kuasa (pocung 26) & Sinamaya (162) \\
\hline 95 & Sang MahaResi (pocung : 29) & \\
\hline 96 & Sang Wisesa (pocung:31) & Sang Purusa (163) \\
\hline 97 & Sang Maha Wiku (VIII.DG:8) & Sang Raja Pertapa (178) \\
\hline 98 & Sang Kawi (DG;8) & Sang Kawi (178) \\
\hline 99 & Sang Kawiswara (DG: 8) & \\
\hline 100 & Sang Kawi (DG:10) & Sang Kawi (179) \\
\hline 101 & Sang Guru (DG:10) & Sang Guru (179) \\
\hline 102 & Sang Kawi (DG;11) & Sang Kawi (180) \\
\hline 103 & Sang Pendeta (DG;11) & Wiku (180) \\
\hline 104 & Sang Narendra yang luhur (DG 12) & - \\
\hline 105 & Pendeta yang Pandai (DG 12) & Yang Mulia Pandita mahautama (181) \\
\hline 106 & Sang Prabu Soman (DG 12) & Yang Mulia Utama Malinatha (181) \\
\hline 107 & Benar-benar ratu agung & Pandita luar biasa ((181) \\
\hline 108 & Pendeta utama (DG 12) & Guru luar biasa (181) \\
\hline 109 & Guru nata kerajaan (DG 13) & - \\
\hline 110 & - & Yang Mulia (181) \\
\hline 111 & Sang Hyang Wisesa (DG 14) & - \\
\hline 112 & Kawi (DG 14) & - \\
\hline 113 & Prabu Darmasonya (DG 14) & Yang Mulia Utama Dharma Sunya (182) \\
\hline 114 & Rehing sang Pendeta (DG 14) & - \\
\hline 115 & Sang Yogiswara (DG 16) & Sang Yoga Utama (184) \\
\hline 116 & Pendeta yang pandai bijakasana (DG 19) & - \\
\hline 117 & Yasadipura II 9DG 19) & - \\
\hline 118 & Paduka Yang Mulia Sang Nerpati Siwi (DG 19) & - \\
\hline
\end{tabular}

\section{SIMPULAN}

Penelitian terhadap Sêrat Darmasunya yang merupakan wujud transformasi dari Kakawin Dharma Śunya menunjukkan hasil bahwa di antara keduanya memiliki isi yang sama meskipun keduanya memiliki perbedaan bentuk dan bahasa, yaitu tembang macapat berbahasa Jawa dan kakawin berbahasa Jawa Kuna. Perbedaan di antaranya ditemukan dengan mengidentifikasi unsur pembentuk karya yang berupa tokoh dan istilah yang digunakan. Adapun alurnya menunjukkan persamaan meskipun ada perbedaan, yaitu pemaparan cerita dalam teks Serrat Darmasunya lebih ringkas jika dibandingkan dengan teks Kakawin Dharma Śūnya. |Hasil analisis tersebut semakin membuktikan bahwa tansformasi yang terjadi disesuaikan dengan

zamannya agar makna yang terkandung dapat terterima dengan mudah oleh pembaca sesuai dengan waktu transformasi teks dilakukan.

\section{DAFTAR PUSTAKA}

Baroroh-Baried, Siti., Sulastin Sutrisno, Siti Chamamah Soeratno, Sawu, Kun Zachrun Istanti. (1994). Pengantar Teori Filologi. Yogyakarta: BPPF Fakultas Sastra Universitas Gadjah Mada.

Barthes, Roland. (1981). Theory of the Text, dalam Robert Young, ed. Untying the Text: A Post Structuralist Reader. Boston: Rouledge \& Kegan Paul.

Behrend, T.E. (1990). Katalog Induk Naskah-baskah Nusantara. MuseumSonobudaya. Jilid 1. Jakarta: Djambatan.

Chamamah-Soeratno, Siti. (1989). "Sastra Lama dan Relevansinya dengan Masa Kini”. (Makalah 
dalam Seminar Bahasa dan Sastra se-Jateng dan DIY). Yogyakarta.

Florida, Nancy K. (1993). Javanese Literature in Surakarta Manuscripts. Volume I. New York: Cornell University.

Istanti, Kun Zachrun. (2010). Transformasi dan Integrasi dalam Kesusastraan Nusantara: Perbandingan Teks Amir Hamzah Melayu dan Jawa. Jurnal Humaniora, 22, 241-249.

Junus, Umar. (1985). Resepsi Sastra: Sebuah Pengantar. Jakarta: Gramedia.

Palguna, IBM Dharma. (1999). Dharma Sunya: Memuja dan Meneliti Siwa. Denpasar: Yayasan Dharma Sastra.

Pigeaud, Th. G. Th. (1967). "Synopsis of Javanese Literature 900-1900 AD”. Dalam Literature of Java, Vol.I. The Hague: Martinus Nijhoff.

Poerbatjaraka, R.M. dan Tardjan Hadidjaja. (1957). Kepustakaan Djawa. Jakarta: Djambatan.

Poerwadarminta, W.JS.(1939). Baoesastra Djawa. Batavia: Groningen/ J.B. Wolter's.
Robson, S.O. (1994). Prinsip-Prinsip Filologi Indonesia (terj. Kentjanawati Gunawan). Jakarta: Publikasi Bersama Pusat Pembinaan dan pengembangan Bahasa dengan Universitas Leiden.

Sudewa, A. (1991). Serat Panitisastra. Yogyakarta: Duta Wacana University Press.

Suratmin. (1981). Darmasonya. Jakarta: Departemen Pendidikan dan Kebudayaan.

Titi Mumfangati. (2007). Terjemahan Darmasunya. Yayasan Kebudayaan Islam Indonesia, nomor koleksi naskah W 267 (C54).

Teeuw, A. (1994). Indonesia Antara Kelisanan dan Keberaksaraan. Jakarta: Pustaka Jaya (2003). "Sastra Indonesia, Pribumisasi, dan Novel Sastra". dalam Among Kurnia Ebo (ed.) Sastra di Titik Nadir; Bunga Rampai Teori Sastra Kontemporer. Yogyakarta: Jendela

Zoetmulder, P.J. (1985). Kalangwan: Sastra Jawa Kuno Selayang Pandang. Jakarta:Djambatan. 